https://doi.org/10.48009/2_iis_2010_97-103

\title{
USING THE ETS MAJOR FIELD TEST IN BUSINESS TO COMPARE ONLINE AND CLASSROOM STUDENT LEARNING
}

\author{
Andrew Tiger, Southeastern Oklahoma State University, atiger@ se.edu \\ Jimmy Speers, Southeastern Oklahoma State University, jspeers@ @e.edu
}

\begin{abstract}
This study demonstrates a method of assessment for an online program of instruction. Based on data taken over the last five years, the study compares the score on the major field test in business (MFT-B) from ETS with the number of core courses taken online, the number of online courses taken at this university, age and the student's GPA in the core courses. No literature was found demonstrating the use of the MFT-B for comparing online and classroom instruction. The data shows that there is no difference in the outcomes for students in online courses and classroom courses. The study will be repeated annually for assessment reporting. Additionally, our study found higher withdrawal rates for online courses when compared to classroom courses.
\end{abstract}

Keywords: Assessment, Online Business Education, AACSB, Assurance of Learning, Major Field Test, MFT

\section{INTRODUCTION}

Research continues to show little difference in student learning between online courses and classroom courses. This general equivalency is clearly demonstrated on Russell's website "nosignificantdifference" and in his book [9]. The purpose of his website is to keep the list of studies up to date. Some show that the classroom is a better delivery system while others show that online students perform better, but the preponderance of evidence is that they are equivalent. In a survey done by WCET and Campus Computing Project $84 \%$ of higher education administrators believed that student outcomes were the same at their institutions [7].

The methods used to compare student outcomes in these studies include projects, research papers, portfolios, qualitative, and quantitative data [13]. The use of student's GPA has also been used in some large studies [8]. Koch's large study looked at over 25,000 student registrations. The purpose of his study was to find factors of success. Most research in now focusing on best practices [6]. Even so, it is important to assess the outcomes at each university.

It cannot be assumed that the technology is being used effectively; therefore the learner's outcomes should be measured and compared. This assessment can assist the faculty in finding the strengths and weaknesses that exist in the online courses. One of the main purposes of assessment is to continuously improve instructional delivery, regardless of the delivery method.

A report by the Institution for Higher Education Policy listed several problems with research in distance learning. Included in the list was research on individual courses instead of programs and a lack of longitudinal studies [4, 14]. This study addresses both of these issues.

Most accrediting agencies and universities require departments to demonstrate that their online and classroom courses are equivalent. For a school of business, the AACSB requires that:

"Schools will be expected to
describe the amount of effort
normally required for the degree.
The descriptive characteristics will
differ by the pedagogical and
delivery characteristics of the
degree. Traditional, campus-based,
education may be described by
contact hours, credithours,
or course equivalencies. Distance
learning programs may require
other metrics and may
depend more heavily on
demonstration of the learning
outcomes. The school should assist
accreditation reviewers by
clarifying the delivery modes and
the kinds and extent of student
effort involved in degree programs
[1].

The Higher Learning Commission's handbook states that a core component of student learning and 
effective teaching is "The organization creates effective learning environments [11]. Therefore, the university must demonstrate that its online courses are equivalent to the classroom courses and that both are effective. Our university has created an Online Learning Council, with a full time director, to manage the online course offerings. This council has focused its efforts on controlling inputs instead of measuring outcomes. They have set up guidelines that promote consistency [10], use an outside peer reviewer [5, 12], encourage the use of creating a collaborative environment, require training for all online faculty and consideration for different learning styles [2].

Each department prepares an assessment report annually which includes online assessment of learning. Random samples of students' work are scored on a rubric to assess competency in the schools goals.

These reporting requirements are due in part to the fact that distance learning enrollments have been growing for more than a decade and are anticipated to grow at an ever increasing rate [7]. One reason for the increase is that students believe that they are receiving an equivalent learning experience [3].

The purpose of this study is to demonstrate a method of research to show that the online courses are equivalent to the classroom courses offered in the school of business at our university. The results are also used, along with individual course assessment, to find strength and weaknesses in the online program. Additionally, the results will assist in fulfilling the requirements of AACSB, The Higher Learning Commission and our university's assessment reporting requirements.

Description of the Study
The school of business offers an undergraduate degree in Business Administration (BBA). The students can major in Accounting, Marketing, Finance, Management or General Business, which are composed of core curriculum, followed by major courses. This core consists of thirteen courses in business knowledge and skills that the faculty has determined to be necessary for all business students to have, regardless of their major. Beginning in 2005, all core courses and management courses are offered as both online and classroom courses. That same year the school began using the web-based major field test in business (MFT-B) from ETS.

The study compares the scores on the (MFT-B) with the percent of core courses taken online, the percent of core courses taken at this university, age, and the student's grade point average (GPA) in the core courses. Although many universities use the MFT-B in their assessment, we have not found a study that uses this test to validate its overall online offerings. The study used data from all graduating students over a four year period who took the MFT-B, $n=136$. Because the students self selected themselves into online courses, there was a concern that a greater number of higher achieving students might have selected the online courses. A comparison of ACT scores and the number of online courses that a student enrolled found no correlation with $\mathrm{r}=0.092$.

\section{Data Collection}

Table 1 shows the summary data for the four years of data collected of graduating seniors from 2005-2008 who took the MFT-B. Column (3) shows that over $22 \%$ of all core courses taken were online, with some students taking over $50 \%$ of their courses online. Column (4) shows the heavy influence of the feeder schools and transfer students with the average number of courses taken elsewhere around $24 \%$.

Table 1. Summary Statistics of MFT-B Students Who Earned BBA from 2005-2008 $(n=136)$

\begin{tabular}{|c|c|c|c|c|c|}
\hline $\begin{array}{c}\text { (1) } \\
\text { Descriptive Statistics }\end{array}$ & $\begin{array}{c}\text { (2) } \\
\text { MFT-B }\end{array}$ & $\begin{array}{l}\% \text { of Core } \\
\text { Taken } \\
\text { Online }\end{array}$ & $\begin{array}{c}(4) \\
\% \text { of Core } \\
\text { Taken at } \\
\text { Host } \\
\text { University }\end{array}$ & Student Age & GPA \\
\hline Average & 153 & $22 \%$ & $76 \%$ & 29 & 2.99 \\
\hline Standard Deviation & 13 & $18 \%$ & $18 \%$ & 6 & 0.57 \\
\hline 5 percentile & 133 & $0 \%$ & $54 \%$ & 24 & 2.00 \\
\hline 95 percentile & 176 & $55 \%$ & $100 \%$ & 43 & 3.82 \\
\hline
\end{tabular}




\section{Assumptions and Analysis}

Five null hypotheses were proposed involving the MFT-B and are shown in Table 2, and multiple linear regression was used to test for relationships. Table 3 shows the multiple linear regression output.

Prior to investigating the hypotheses, multiple regression assumptions were tested. Figure 1 shows that residuals were approximately normal. Also, no correlation existed between variables except that age is inversely correlated (-0.40) with percentage of core courses taken at the host university. If used to forecast, the model would need to consider these two variables together, and not independently. Finally, the Durbin-Watson statistic was 1.92 , showing no autocorrelation between observations.

It would be expected that there is a relationship between GPA and the MFT-B and is not surprising to find that $\mathrm{R}^{2}=0.26$. This means that $26 \%$ of the variation in the MFT_B can be explained by the independent variables. Looking at the t-score and $\mathrm{P}$ - value for each independent variables, only the GPA is shown to have a relationship with the MFT_B.

Charts of the individual factors and their impact on the MFT-B scores are shown in Figures $2-6$.

Figure 2 shows no evidence that MFT-B scores are influenced by how many online courses are taken. If there were a problem with the online courses, the students who take more online courses would score lower on the MFT-B. Figure 3 shows no evidence that students who take core classes elsewhere have an advantage or disadvantage in learning as measured by the MFT-B. This was a concern because some of our students take accounting courses at a nearby Community College. Figure 4 shows a very weak relationship that older, non-traditional students may score lower than traditional students between the ages 20 and 30. Figure 5 shows that a moderate relationship between the MFT-B and GPA does exist. Figure 6 shows that scores have not significantly changed in the last four years.

\section{Table 2. Null Hypotheses for the MFT-B}

Null Hypothesis, $\mathbf{H}_{0}$ : No relationship exists between learning as measured by the MFT-B and ...

(1) percentage of online business core courses taken

(2) percentage of business core courses taken at home university

(3) student age

(4) GPA

(5) Year the exam was taken 
Table 3. MS-Excel Multiple Linear Regression Results

\begin{tabular}{|c|c|c|c|c|c|}
\hline \multicolumn{2}{|c|}{ Regression Statistics } & & & & \\
\hline Multiple R & 0.51 & & & & \\
\hline R Square & 0.26 & & & & \\
\hline Adjusted R Square & 0.23 & & & & \\
\hline Standard Error & 11.09 & & & & \\
\hline Observations & 136 & & & & \\
\hline \multicolumn{6}{|l|}{ ANOVA } \\
\hline & $d f$ & $S S$ & $M S$ & $F$ & P-Value \\
\hline Regression & 5 & 5510.53 & 1102.11 & 8.96 & 0.00 \\
\hline Residual & 130 & 15993.00 & 123.02 & & \\
\hline \multirow[t]{2}{*}{ Total } & 135 & 21503.53 & & & \\
\hline & Coefficients & $S E$ & $t$ Stat & P-value & \\
\hline Intercept & 121.92 & 11.75 & 10.38 & 0.00 & \\
\hline \%_Core_Online & -3.41 & 5.58 & -0.61 & 0.54 & \\
\hline \%_Core_at_Host_University & -1.18 & 5.94 & -0.20 & 0.84 & \\
\hline Age & -0.16 & 0.17 & -0.96 & 0.34 & \\
\hline GPA & 10.69 & 1.71 & 6.27 & 0.00 & \\
\hline Year & 0.92 & 1.15 & 0.80 & 0.43 & \\
\hline
\end{tabular}

Figure 1. Multiple Regression Residuals

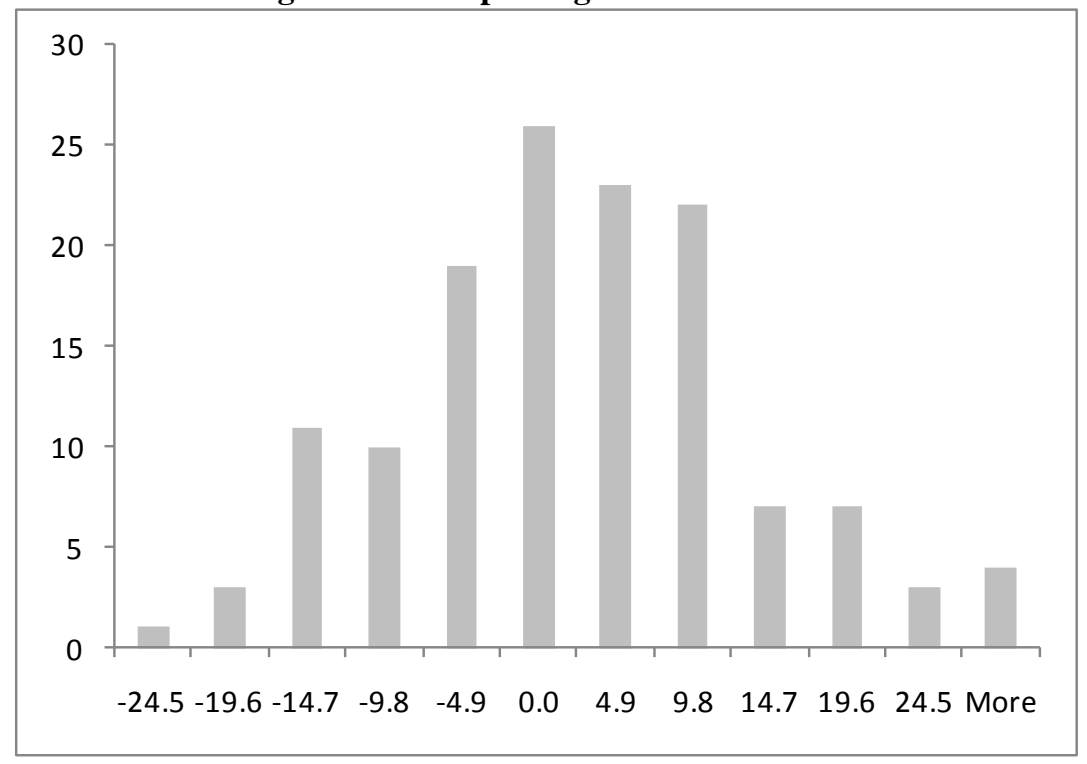


Figure 2. MFT-B vs. \% Online Business Core Courses

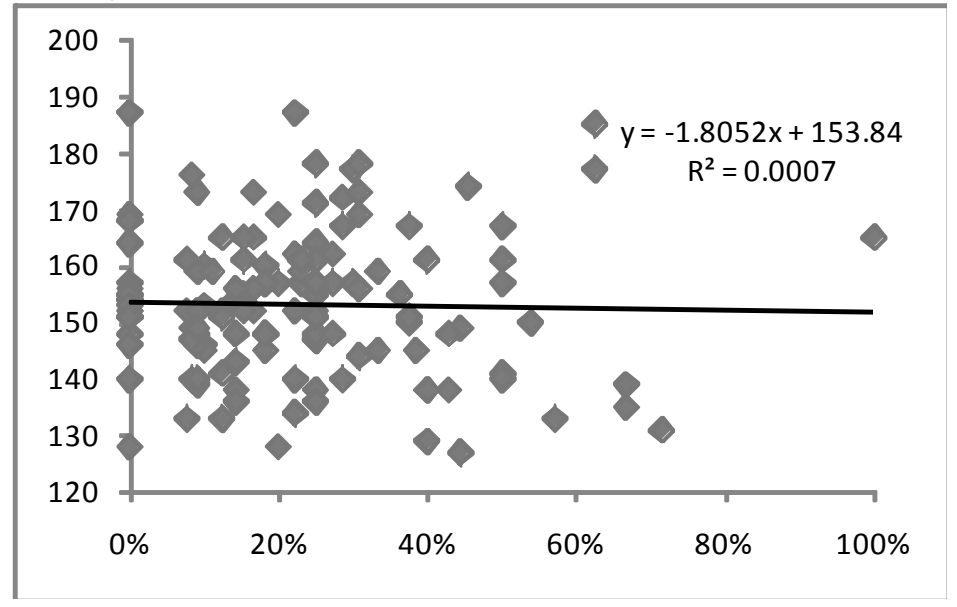

Figure 3. MFT-B vs. \% Business Core Courses Taken at the BBA University

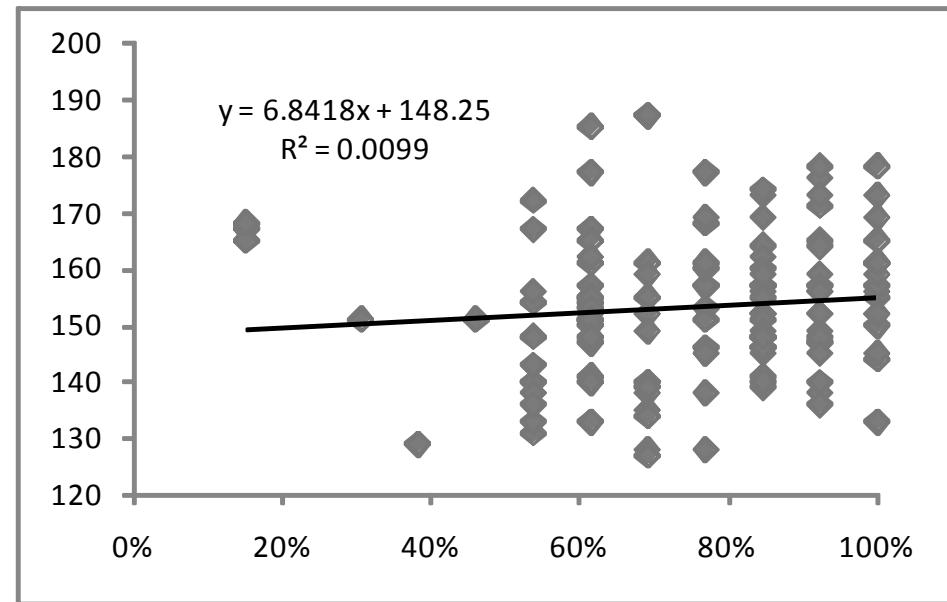

Figure 4. MFT-B vs. Student Age

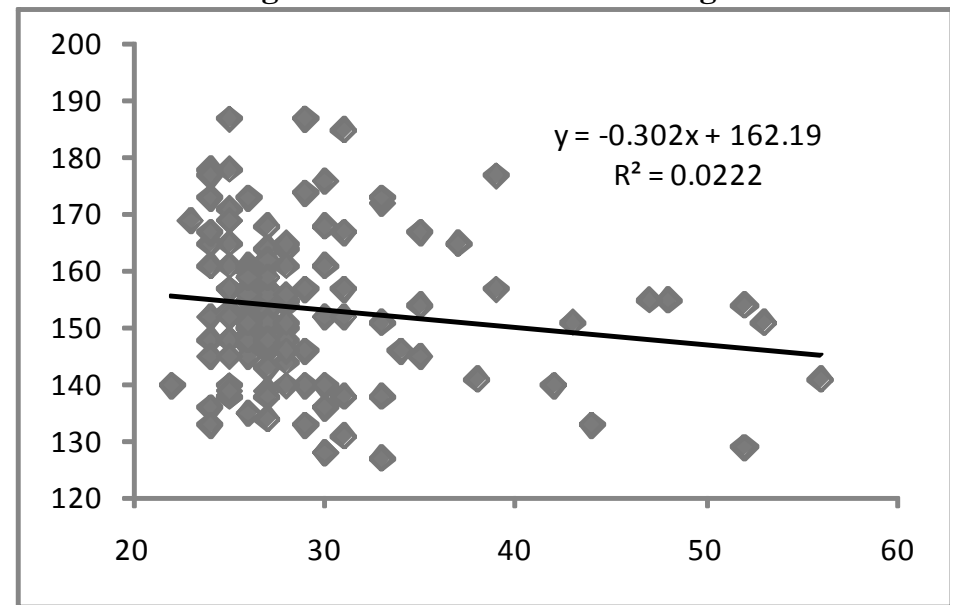


Figure 5. MFT-B vs. GPA

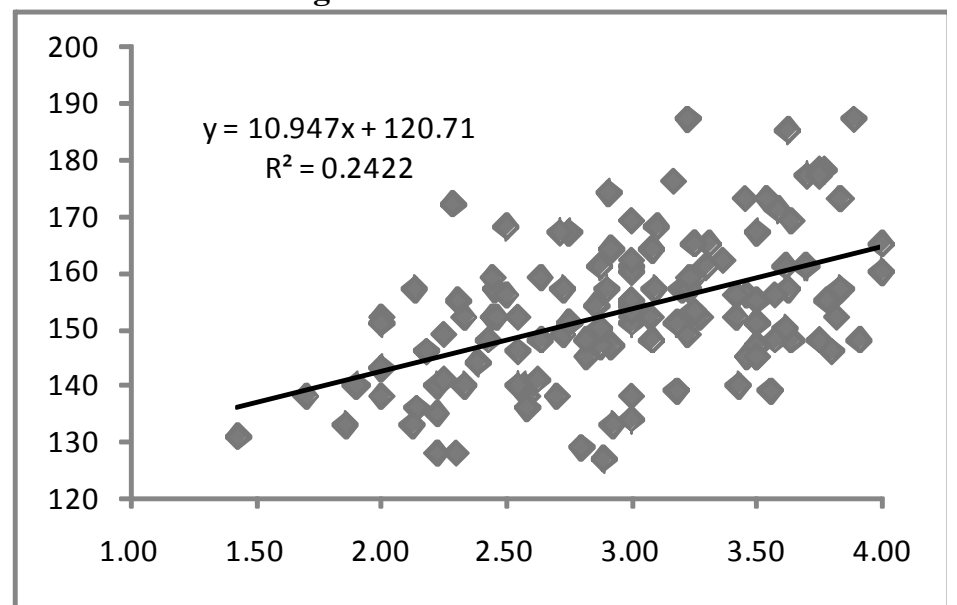

Figure 6. MFT-B vs. Year

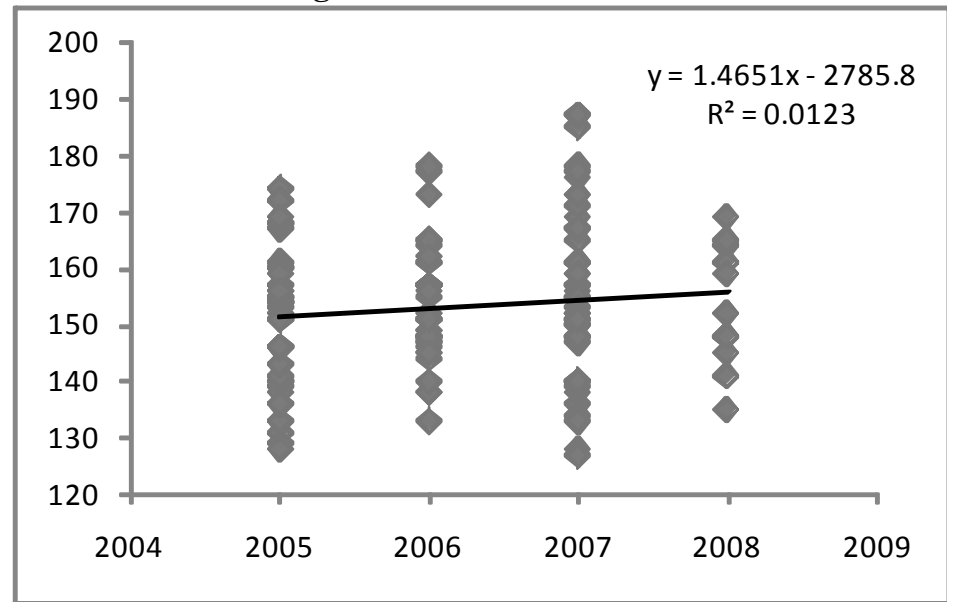

One other item that was addressed was the withdrawal rate for online and classroom courses. The percentage of withdrawals in online courses was significantly higher than in classroom courses at the home university with $\mathrm{z}=4.857$.

\section{Conclusions and Recommendations}

The results show that at this time, there are no significant difference in the overall online program and the classroom core classes in the school of business. There are, however, areas that could be improved. Further study needs to be done to determine why the withdrawal rate is higher in online courses. Also needing further study is the fact that older students score slightly lower on the MFT-B.

This study will be repeated every year and the results included in the assessment reports for the university and AACSB. It must be determined how many years of data to include in future studies.

\section{REFERENCES}

AACSB Standards, 2010, Eligibility Procedures and Accreditation Standards for Business Accreditation, AACSB International - The Association to Advance Collegiate Schools of Business, retrieved March 22, 2010 http://www.aacsb.edu/accreditation/AAACSBSTANDARDS-2010.pdf

Balanko, S., (2002), REVIEW AND RESOURCES: Online Education Implementation and Evaluation, Office of Educational Assessment, OEA Report 0111, Retrieved March 23, 2010 from: http://www.washington.edu/oea/pdfs/reports/OE AReport0211.pdf 
Dobbs, R., Waid, C., Carmen, A., STUDENTS' PERCEPTIONS OF ONLINE COURSES: The Effect of Online Course Experience, The Quarterly Review of Distance Education, Volume 10(1), 2009, pp. 9-26

Fiona F., Xin T., \& Soon H. (2004). An Empirical Investigation on End-Users' Acceptance of Enterprise Systems. Information Resources Management Journal, 17(3), 32-51. Retrieved April 22, 2010, from ABI/INFORM Global. (Document ID: 644561351).

Fredericksen, E., Pickett, A., Pelz, W., Swan, K., and Shea, P. (2000). Student satisfaction and perceived learning with online courses: Principles and examples from the SUNY learning network. In J. Bourne (Ed.) Online Education: Learning effectiveness and faculty satisfaction: Volume 1. (p. 7-36). Needham, MA.: Sloan-C.

Grandzol, J., Grandzol, C., (2006), Best Practices for Online Business Education, International Review of Research in Open and Distance Learning, Volume 7, Number 1.

Green, K., Managing Online Education: The 2009 WCET-Campus Computing Project Survey of Online Education, retrieved March 22, 2010 from http://www.educause.edu/Resources/ManagingOnlin eEducationThe2009/188308, (ID: CSD5755)

Koch, J., (2006). Public Investment in University Distance Learning Programs: Some PerformanceBased Evidence. Atlantic Economic Journal, 34(1), 23. Retrieved September 26, 2009, from ABI/INFORM Global. (Document ID: 1013181161).

Russell, T. L. (2005). No significant difference phenomenon. Retrieved March 23, 2010 from: http://www.nosignificantdifference.org/

Swan, K. (2003). Learning effectiveness: What the research tells us. In J. Bourne and J. C. Moore (Eds.) Elements of Quality Online Education: Practice and direction. (p. 13-45). Needham, MA.: Sloan-C.

The Higher Learning Commission, 2003, Handbook of Accreditation, The Higher Learning Commission, Retrieved March 23, 2010 from: https://content.springcm.com/content/DownloadDo
cuments.ashx?Selection=Document $\% 2 \mathrm{C} 10611003 \%$ 3B\&accountId=5968

Thompson, M. M. (2003). Faculty satisfaction in the online teaching-learning environment. In J. Bourne and J. C. Moore (Eds.) Elements of Quality Online Education: Practice and direction. (p. 189-212). Needham, MA.: SloanC.

Tucker, S., Hodge, E., 2004, Quality Assurance of Distance Education: Multiple Assessment Measures Used in a Business, Career and Technical Education Department, Turkish Online Journal of Distance Education-TOJDE, 5,(2), p. 13-21, Retrieved March 23, 2010 from: http://tojde.anadolu.edu.tr/tojde14/df/volume5_n umber2.pdf

What's the Difference? A Review of Contemporary Research on the Effectiveness of Distance Learning in Higher Education (1999), The Institute for Higher Education Policy, Retrieved March 23, 2010 from:

http://www.ihep.org/assets/files/publications/sz/WhatDifference.pdf 